\title{
The Biodiversity of Thermoduric Bacteria Isolated from Whey
}

Joseph Meade

University College Dublin, Ireland

Seamus Fanning

University College Dublin, Ireland, sfanning@ucd.ie

Kevinia McGill

University College Dublin, Ireland

See next page for additional authors

Follow this and additional works at: https://arrow.tudublin.ie/schfsehart

Part of the Food Science Commons

\section{Recommended Citation}

Meade, J., Fanning, S., McGill, K. and Walsh, C. (2012) The bidiversity of thermoduric bacteria isolated from whey. Journal of food safety, 32, 255-261. doi:10.1111/j.1745-4565.2012.00375.x

This Article is brought to you for free and open access by the School of Food Science and Environmental Health at ARROW@TU Dublin. It has been accepted for inclusion in Articles by an authorized administrator of ARROW@TU Dublin. For more information, please contact arrow.admin@tudublin.ie, aisling.coyne@tudublin.ie, gerard.connolly@tudublin.ie.

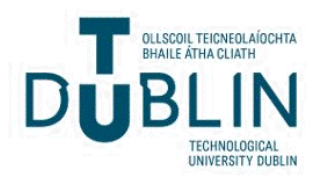


Authors

Joseph Meade, Seamus Fanning, Kevinia McGill, and Ciara Walsh

This article is available at ARROW@TU Dublin: https://arrow.tudublin.ie/schfsehart/254 


\title{
THE BIODIVERSITY OF THERMODURIC BACTERIA ISOLATED FROM WHEY
}

\author{
C. WALSH, J. MEADE, K. MCGILL and S. FANNING ${ }^{1}$ \\ UCD Centre for Food Safety \& Centre for Food-borne Zoonomics, School of Public Health Physiotherapy \& Population Science, School of Veterinary \\ Medicine, UCD Veterinary Sciences Centre, University College Dublin, Belfield, Dublin 4, Ireland
}

${ }^{1}$ Corresponding author. TEL: 353-1-716082; FAX: 353-1-7166091; EMAIL: sfanning@ucd.ie

Received for Publication July 27, 2011

Accepted for Publication March 13, 2012

doi:10.1111/j.1745-4565.2012.00375.x

\begin{abstract}
Thermoduric gram-positive bacteria are indigenous in milk, cheese, whey and other dairy products. They are capable of surviving heat processes and can result in quality defects and a shortened product shelf life. In Ireland, premium products such as whey protein concentrate (WPC) are often adversely affected by these microorganisms, particularly during the winter months. A high bacterial count in the WPC can result in the product being sold at a lower grade, with an overall loss of revenue for the manufacturer.

This study recovered thermoduric bacterial isolates $(n=140)$ from an Irish WPC process during the months of November-February. Using molecular 16S $r R N A$ gene identification, Bacillus licheniformis, Microbacterium lacticum, Staphylococcus warneri, Enterococcus durans and Bacillus subtilis were recorded as the predominant microorganisms in this process line. This is the first known study to report the detection of Microbacterium phyllosphaerae, Neisseria subflava, Rothia aeria and Streptococcus mitis in dairy produce or indeed in any food product. The identification of bacteria at various stages of the WPC production process will support future measures in reducing/removing microorganisms from the process line in question and assist the dairy manufacturer in tackling this costly problem.
\end{abstract}

\section{PRACTICAL APPLICATIONS}

Through the use of $16 S$ rRNA gene typing, we have accurately identified the bacteria that were present at various stages of the WPC production process in this facility. Molecular methods are not routinely used in this setting. Nonetheless, they can confer important advantages in terms of their accuracy and speed. These findings support a translated improvement in bacterial identification, allowing us to not only trace but also to strategically reduce/eliminate certain microflora from the production process. The latter step can have the effect of reducing the overall bacterial load of the matrix while simultaneously improving its shelf-life characteristics. These findings will assist in the development of measures to improve the quality and safety of WPC production at this plant. This study highlights the potential benefits of using molecular techniques in a food processing environment.

\section{INTRODUCTION}

The main goal of pasteurization and other heat treatments in the dairy and other food industries is to eliminate pathogens that may be present in food products, such as milk (Pearce et al.2012). In the absence of post-treatment contamination, the microorganisms that survive pasteurization determine the shelf life of pasteurized milk, or in the case of dairy by-products such as whey, they determine the quality and grade of the product (Haraguchi et al. 2010).

Unprocessed whey supports microbial growth (Varnam and Sutherland 2001; Lazzi et al. 2004), so care must be taken to minimize contamination. Improperly sanitized equipment and incorrect storage can lead to high bacterial counts 
(Monfredini et al. 2011). The elimination of thermoduric bacteria from the final product can be challenging, even when compliance with appropriate measures has taken place. Heatresistant strains may be capable of surviving pasteurization, evaporation, spray-drying or other related heat stresses (Pintado et al.2001). Thermoduric strains commonly associated with dairy products and dairy processing lines include species of streptococci, staphylococci, enterococci and spores of Bacillaceae (De Garnica et al. 2010). Surveillance and identification of these bacteria may indicate how and where their numbers can be reduced or eliminated from the production process. This information can be used to assist dairy manufacturers in their continuing efforts to improve the quality and microbial safety of dairy products, including important by-products such as whey protein concentrate (WPC). However, the authors did not find any peer-reviewed publications examining the microflora of WPC, suggesting that research in this field is lacking.

In this study, we report the microbiological surveillance of a WPC production line. Bacteria recovered by conventional bacteriological methods were identified using molecular analysis of the corresponding $16 S$ rRNA genes.

\section{MATERIALS AND METHODS}

\section{Isolation of Bacterial Strains}

The WPC process in an Irish dairy plant was sampled over a 4-month period (November-February). Random samples of raw milk $(10 \times 20 \mathrm{~mL})$, pasteurized milk $(10 \times 20 \mathrm{~mL})$, whey and casein $(10 \times 20 \mathrm{~mL})$ and WPC $(26 \times 20 \mathrm{~g})$ were microbiologically analyzed (separately), and bacterial isolates recovered were identified.

\section{Isolation of Mesophile Aerobic Spores from the WPC Process}

Eleven grams of sample was suspended in $99 \mathrm{~mL}$ of buffered peptone water (Oxoid, Cambridge, U.K.), $5 \mathrm{~mL}$ of which was pipetted into a test tube and placed in a water bath at $80 \mathrm{C}$ $( \pm 1 \mathrm{C})$ for $12 \mathrm{~min}$. The test tube was then removed from the water bath and cooled (to below 10C), then poured into sterile Petri dishes with $15 \mathrm{~mL}$ of molten $(45 \mathrm{C} \pm \mathrm{C})$ plate count agar (Oxoid). Plates were then incubated at 30C ( $\pm 1 \mathrm{C})$ for $72 \mathrm{~h}( \pm 2 \mathrm{~h})$, and where possible, three random colonies with varying morphology were selected for identification.

\section{Isolation of Thermoduric Mesophilic Organisms from the WPC Process}

A further $5 \mathrm{~mL}$ of the suspension media was pipetted into a test tube and incubated at $63 \mathrm{C}( \pm 1 \mathrm{C})$ for $35 \mathrm{~min}$ and then cooled (to below 10C). One milliliter of the dilution was then transferred into a sterile Petri dish with $15 \mathrm{~mL}$ of molten (45C \pm C) milk plate count agar (Merck, Clonmel, Ireland). When the agar had set, the plates were overlaid with a further $5 \mathrm{~mL}$ of agar and incubated at $30 \mathrm{C}( \pm 1 \mathrm{C})$ for $72 \mathrm{~h}( \pm 4 \mathrm{~h})$. Once again, where possible, three random colonies with varying morphology were then selected for identification.

\section{DNA Extraction and Microbial Identification}

DNA was isolated from a loop of culture using a PrepMan Kit (Applied Biosystems, Carlsbad, CA). Polymerase chain reaction (PCR) was carried out in $20 \mu \mathrm{L}$ volumes using $18 \mu \mathrm{L}$ (AmpliTaq Gold, Applied Biosystems) and $2 \mu \mathrm{L}$ of genomic DNA $(0.1-0.5 \mu \mathrm{g} / \mu \mathrm{L})$. The $16 S \mathrm{rDNA}$ gene primers used in this study were as follows: forward $5^{\prime}$-TGG AGA GTT TGA TCC TGG CTC AG-3' and reverse 5'-TAC CGC GGC TGC TGG CAC-3'. Thermal cycling was carried out as follows: initial denaturation $95 \mathrm{C}$ for $30 \mathrm{~s}$, denaturation $95 \mathrm{C}$ for $10 \mathrm{~s}$, annealing $55 \mathrm{C}$ for $20 \mathrm{~s}$, extension $72 \mathrm{C}$ for $30 \mathrm{~s}$, repeat cycle 28 times (steps 2, 3 and 4) and a final extension of $72 \mathrm{C}$ for $1 \mathrm{~min}$.

\section{5 rRNA Analysis}

All of the recovered isolates were subjected to 16S rRNA gene analysis to confirm their identification. Following PCR, amplicons produced were recovered and sequenced commercially by Accugenix. Sequences were compared against the commercial database of all isolates. Neighbor-joining trees (Saitou and Nei 1987) were constructed from isolates identified to confirm their links to the corresponding genus and to assess their relationships therein (see Figs. 1-4).

\section{RESULTS}

Four ingredients from the WPC production line were microbiologically sampled, including raw milk, pasteurized milk, whey/casein and finally WPC (Table 1).

\section{Thermoduric Aerobic Spore formers}

The aerobic spore former counts of the WPC product were found to range from $1 \times 10^{2}$ to $2 \times 10^{3} \mathrm{cfu} / \mathrm{g}$ over the four winter months examined, with the average count being $1 \times 10^{3} \mathrm{cfu} / \mathrm{g}$.

Seven different species of Bacillus (see Fig. 1) and one strain of Paenibacillus lactis were recovered from the WPC process in this study. From the random colonies selected, thermoduric aerobic spore formers made up $62 \%$ of the isolates identified in raw milk, $57 \%$ of pasteurized milk, $19 \%$ of whey/casein and 34\% of WPC. Of these, Bacillus licheniformis (19\%), Bacillus fusiformis (9\%), Bacillus pumilus (4\%) and Bacillus mojavensis (2\%) were isolated in the final WPC product after the whey had been pasteurized (72C for $15 \mathrm{~s}$ ) 


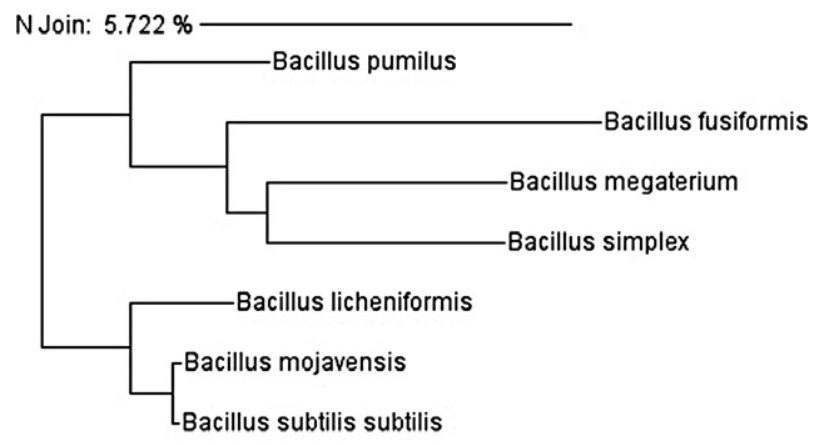

N Join: $6.777 \%$

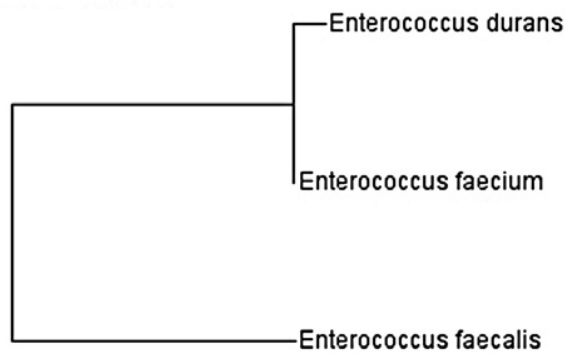

FIG. 1. NEIGHBOR-JOINING TREES FOR BACILLUS AND ENTEROCOCCUS SPECIES

and spray-dried (190C for $20 \mathrm{~min})$. B. licheniformis $(n=36)$ was the most frequently isolated bacteria in the final WPC and all at four points sampled in the WPC production process (Table 1).

\section{Thermoduric Mesophilic Organisms}

The thermoduric mesophilic counts were found to range from $3 \times 10^{2}$ to $5 \times 10^{5} \mathrm{cfu} / \mathrm{g}$ in WPC over the same four winter months and the average count was found to be $2 \times 10^{4} \mathrm{cfu} / \mathrm{g}$.

Twenty-seven different species of thermoduric mesophile were recovered from the WPC process in this study (see Figs. 2-4). From the random colonies selected, thermoduric mesophiles made up 38\% of isolates identified in raw milk, $43 \%$ in pasteurized milk, $81 \%$ in whey/casein and $66 \%$ in WPC. Microbacterium lacticum (15\%) and Kocuria varians (15\%) were the second most commonly isolated bacteria from the final WPC (see Table 1). M. lacticum, Enterococcus durans and Staphylococcus warneri were recovered from all four stages of the WPC process sampled. More interestingly, two gram-negative isolates (Pseudomonas cedrina and Neisseria subflava) were also recovered from the final WPC product.
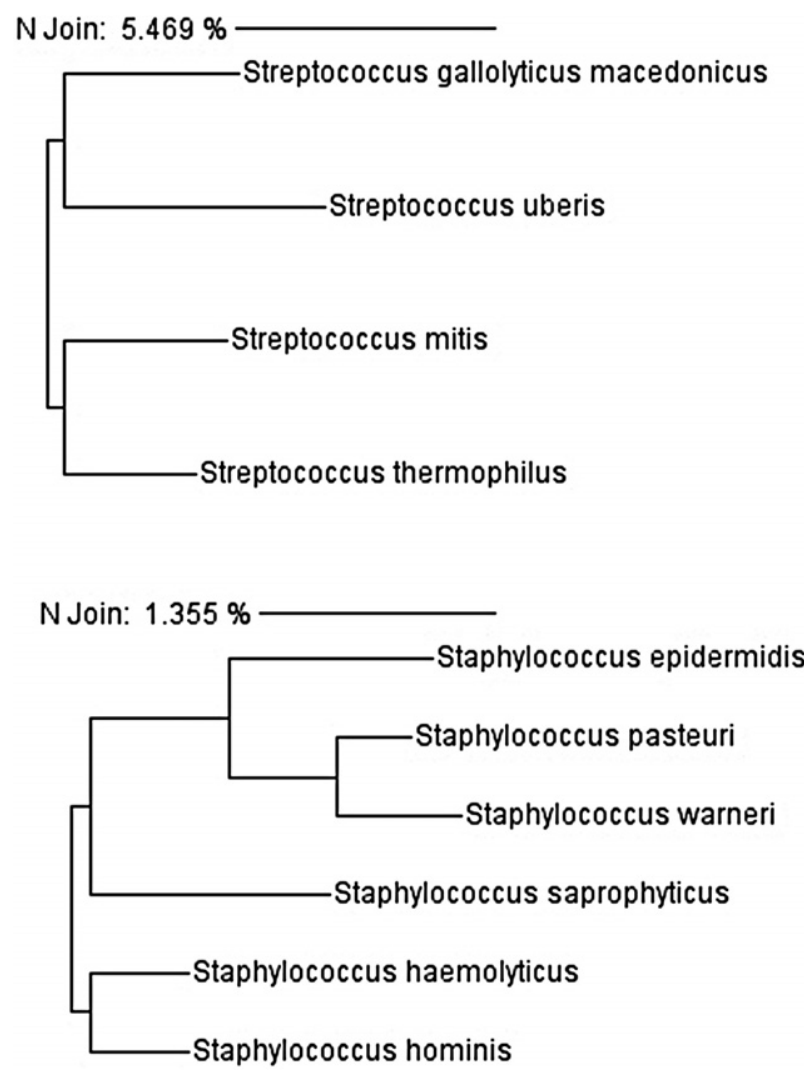

FIG. 2. NEIGHBOR-JOINING TREES FOR STREPTOCOCCUS AND STAPHYLOCOCCUS SPECIES

\section{DISCUSSION}

\section{Thermoduric Aerobic Spore formers}

The Bacillus spp. and P. lactis strains identified in this study have been previously associated with dairy product or other food sources (Scheldemann et al. 2004; From et al. 2005; De Jonghe et al.2010; Reginensi et al.2011), including one report of the typically environmental strain of Bacillus simplex in surimi (Coton et al.2011) and another of the environmental strain of B. fusiformis in cocoa (Quattara et al. 2011). B. licheniformis was the most frequently isolated bacteria in this study and was recovered at all production stages sampled in the WPC manufacturing process. This concurs with a study by Janstova and Lukasova (2001), who reported that B. licheniformis was more heat resistant than other serotypes of this genus, when 21 spores were compared with the spores of 18 isolates of B. subtilis, 6 of B. cereus, 5 of B. sphaericus and a range of other Bacillaceae. It is also in agreement with reports indicating that $B$. licheniformis and B. cereus are the predominant bacteria associated with dairy processing (Crielly et al. 1994; Pácová et al. 1996; Banyko and Vyletelova 2009). Unusually, no $B$. cereus isolates were recovered in this study. 
N Join: $2.867 \%$
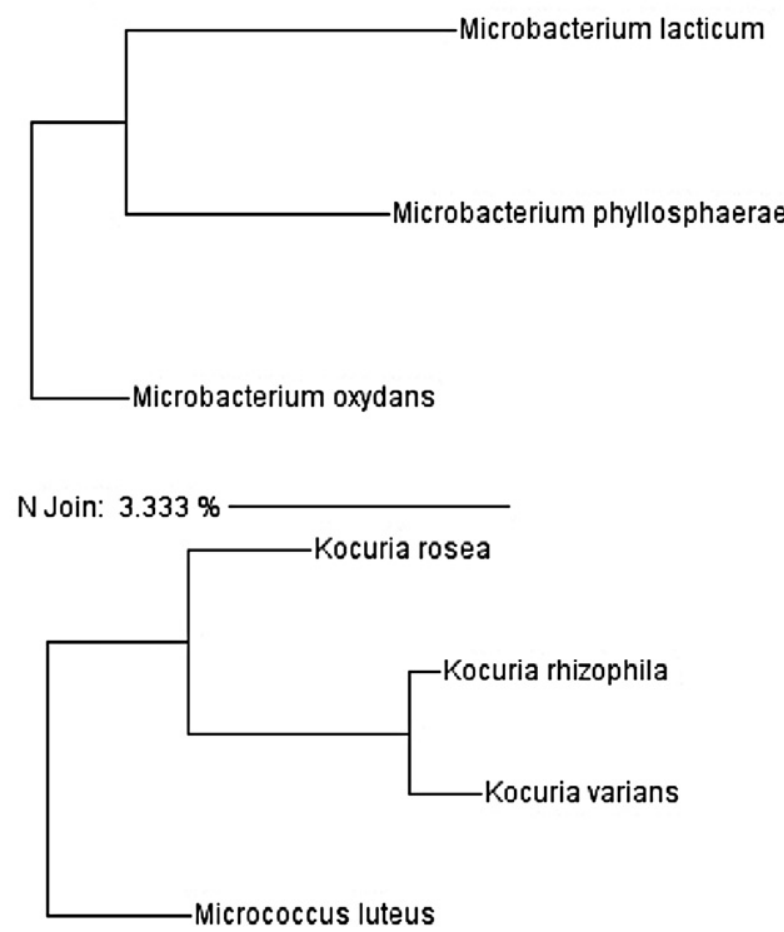

FIG. 3. NEIGHBOR-JOINING TREES FOR MICROBACTERIUM AND MICROCOCCUS SPECIES

While this may be attributed to farming practices/hygiene and production protocols, it is most likely the result of the seasonality of the sampling. The incidence of mesophilic bacilli (including $B$. licheniformis) is conversely reported to be higher during the winter months (when our study took place), while the prevalence of psychrotrophic bacilli (B. cereus) are greater in late summer and autumn (Sutherland and Murdoch 1994; Lin et al. 1998). In addition, Sutherland and Murdoch (1994) reported that established cultures of B. licheniformis have an antagonistic effect on B. cereus at

N Join: $2.358 \%$

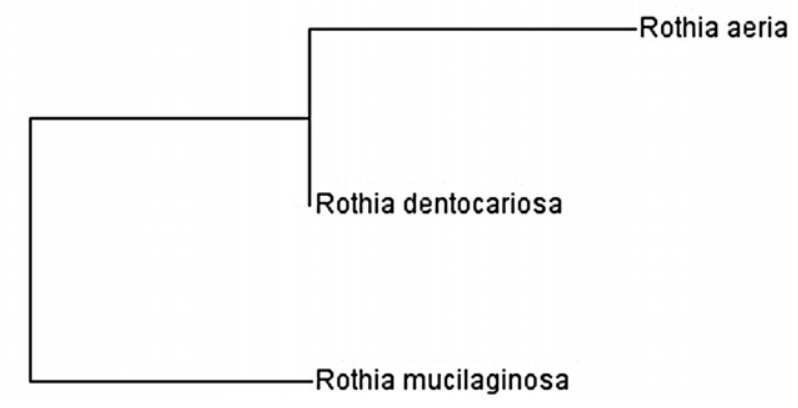

FIG. 4. NEIGHBOR-JOINING TREE FOR ROTHIA SPECIES temperatures as low as 6C, indicating problems with the coexistence of both species within a production line.

\section{Thermoduric Mesophilic Organisms}

All thermoduric mesophilic organisms, with the exception of four isolates (Microbacterium phyllosphaerae, N. subflava, Rothia aeria and Streptococcus mitis), identified during this study are commonly associated with food products, particularly dairy products (Holley et al. 2002; Pasciak et al. 2004; Burton et al. 2005; Park et al. 2005; Martin et al. 2006; El-Baradei et al. 2007). However, this is the first known study to report the detection of M. phyllosphaerae, N. subflava, R. aeria and S. mitis in dairy produce or indeed in any food product. It is important to note (particularly with reference to Microbacterium and Streptococcus) that similar studies identifying bacteria in food and dairy processing have used phenotypic protocols to identify isolates to the genus level rather than PCR-based techniques to identify isolates to the species level (Angula et al. 1989; Albenzio et al. 2001; Holm et al. 2004). It is therefore more likely that these bacteria have been previously isolated from food, but that they were not been fully identified at the time.

The thermoduric mesophiles recovered in this study, particularly the gram-positive rods, are typically associated with poor udder hygiene and equipment cleaning, while Staphylococcus spp. and Streptococcus spp. are more commonly associated with bovines infected with mastitis (Pinzon-Sanchez and Ruegg 2011). Many of these strains can be traced through several stages of the WPC product (particularly M. lacticum, E. durans and S. warneri), highlighting the difficulty in eradicating them from the process. The heat resistance of many of these microorganisms in dairy processing has been previously documented (Albenzio et al. 2001; Holm et al. 2004).

Two gram-negative isolates (P. cedrina and N. subflava) were also recovered from the final WPC product. Unlike gram-positive bacteria, gram-negative bacteria tend to be susceptible to heat, suggesting that contamination with these isolates occurred after the product had received heat treatment. High levels $\left(10^{4} \mathrm{cfu} / \mathrm{g}\right)$ of gram-negative bacteria (particularly Pseudomonas) have been reported in raw bulk tank milk (Holm et al. 2004), suggesting that cross-contamination from raw milk may have occurred.

This study revealed a large variation in the thermoduric bacteria (mesophiles/spore formers) isolated from the final WPC product. While bacteria typically associated with dairy processing were recovered (B. licheniformis, M. lacticum, S. warneri, E. durans and Bacillus subtilis), so too were several unusual and unexpected isolates (M. phyllosphaerae, N. subflava, R. aeria and S. mitis). The prevalence of numerous heat-resistant strains throughout the WPC process suggests that steps other than heat processing are required to reduce the persistence of these bacteria within the production 


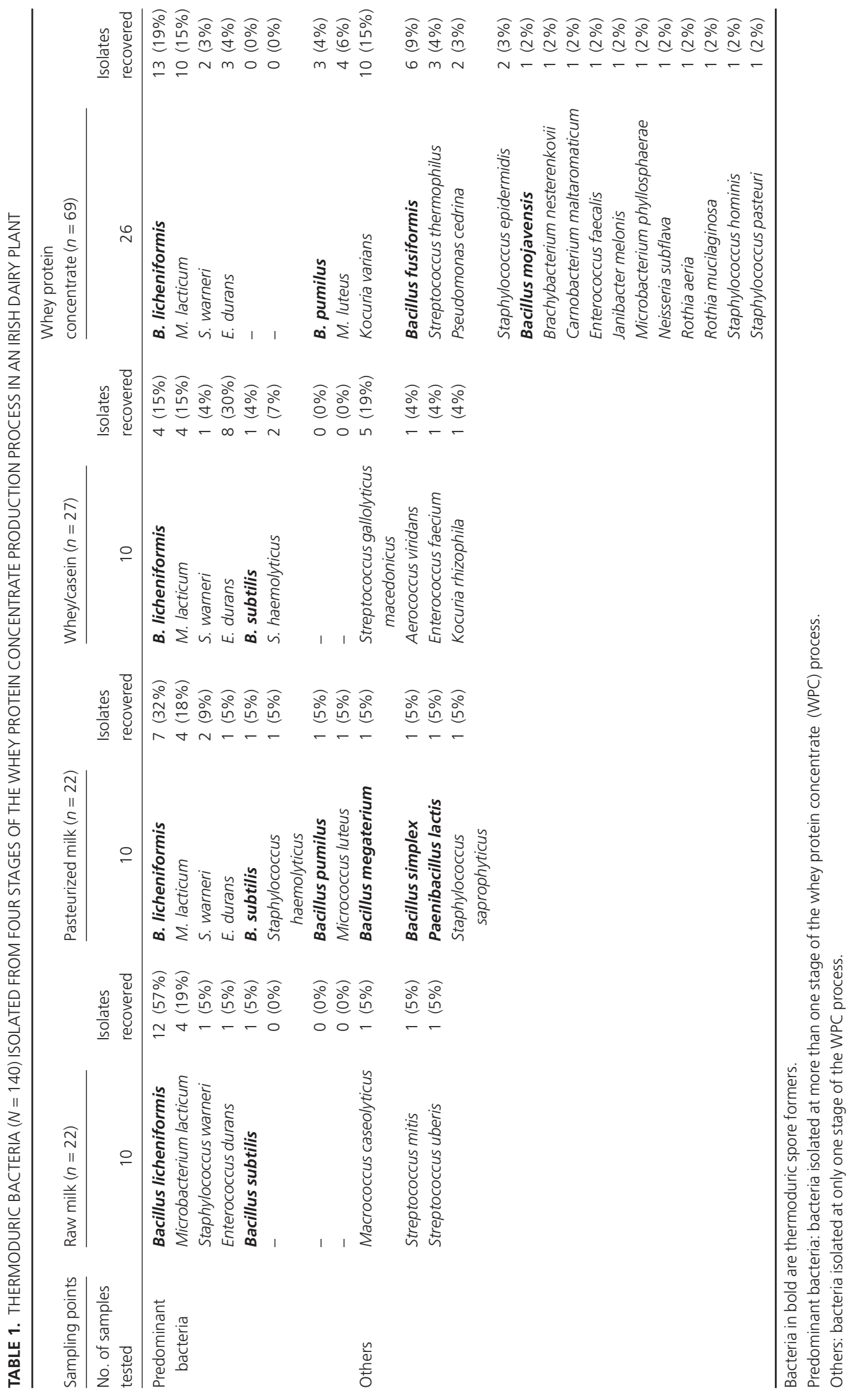


process. Factory hygiene and potential mechanisms of crosscontamination between various processing steps should be closely examined. Emphasis on equipment hygiene, particularly with regard to biofilm-producing species like Bacillus, and the provision of adequate refrigeration are important.

The molecular identification of bacterial populations associated with food processing can assist in the reduction/ elimination of problematic microorganisms from food production lines. Our findings will assist this dairy manufacturer in developing effective strategies for bacterial control, with a view to improving product quality and safety at this plant.

\section{ACKNOWLEDGMENTS}

The authors would like to thank Prof. M. Walsh of the Department of Mathematics and Prof. S. Emerson of the Department of Statistics at Oregon State University for their assistance with this paper.

\section{REFERENCES}

ALBENZIO, M., CORBO, M.R., REHMAN, S.U., FOX, P.F., DE ANGELIS, M., CORSETTI, A., SEVI, A. and GOBBETTI, M. 2001. Microbiological and biochemical characteristics of Canestrato Pugliese cheese made from raw milk, pasteurized milk or by heating the curd in hot whey. Int. J. Food Microbiol. 67, 35-48.

ANGULA, L., LORENZO, A. and RIVEIRO, M. 1989. Isolation and identification of thermoduric flora of raw cow's milk from the Province of Pontevedra. Modern Microbiological Methods for Dairy Products. International Dairy Federation. 8901, 122-128.

BANYKO, J. and VYLETELOVA, M. 2009. Determining the source of Bacillus cereus and Bacillus licheniformis isolated from raw milk, pasteurised milk and yoghurt. Lett. Appl. Microbiol. 48, 318-323.

BURTON, J.P., CHILCOTT, C.N. and TAGG, J.R. 2005. The rationale and potential for the reduction of oral malodour using Streptococcus salivarius probiotics. Oral Dis. 11, 29-31.

COTON, M., DENIS, C., CADOT, P. and COTON, E. 2011. Biodiversity and characterisation of aerobic spore-forming bacteria in surimi seafood products. Food Microbiol. 28, 252-260.

CRIELLY, E.M., LOGAN, N.A. and ANDERTON, A. 1994. Studies on the Bacillus flora of milk and milk products. J. Appl. Bacteriol. 77, 256-263.

DE GARNICA, M.L., SANTOS, J.A. and GONZOLA, C. 2010. Influence of storage and preservation on microbiological quality of silo ovine milk. J. Dairy Sci. 94, 1922-1927.

DE JONGHE, V., COOREVITS, A., DE BLOCK, J., VAN COILLIE, E., GRIJSPEERDT, K., DE VOS, P. and HEYNDRICK, M. 2010.
Toxinogenic and spoilage potential of aerobic spore-formers isolated from raw milk. Int. J. Food Microbiol. 136, 318-325.

EL-BARADEI, G., DELACROIX-BUCHET, A. and OGIER, J.-C. 2007. Biodiversity of bacterial ecosystems in traditional Egyptian domiati cheese. Appl. Environ. Microbiol. 73, 1248-1255.

FROM, C., PUKALL, R., SCHUMANN, P., HORMAZABAL, V. and GRANUM, P.E. 2005. Toxin-producing ability among Bacillus spp. outside the Bacillus cereus group. Appl. Environ. Microbiol. 71, 1178-1183.

HARAGUCHI, F.K., PEDROSA, M.L., PAULA, H., SANTOS, R.C. and SILVA, M.E. 2010. Evaluation of biological and biochemical quality of whey protein. J. Med. Food 13, 1505-1509.

HOLLEY, R.A., GUAN, T.Y., PEIRSON, M. and YOST, C.K. 2002. Carnobacterium viridans sp. nov., an alkaliphilic, facultative anaerobe isolated from refrigerated, vacuum-packed bologna sausages. Int. J. Syst. Evol. Microbiol. 52, 1881-1885.

HOLM, C., JEPSEN, L., LARSEN, M. and JESPERSEN, L. 2004. Predominant microflora of downgraded Danish bulk tank milk. J. Dairy Sci. 87, 1151-1157.

JANSTOVA, B. and LUKASOVA, J. 2001. Heat resistance of Bacillus spp. spores isolated from cow's milk and farm environment. Acta Vet. Brno 70, 179-184.

LAZZI, C., ROSSETTI, L., ZAGO, M., NEVIANA, E. and GIRAFFA, G. 2004. Evaluation of bacterial communities belonging to natural whey starters for Grana Padano cheese by length heterogeneity-PCR. J. Appl. Microbiol. 96, 481-490.

LIN, S., SCHRAFT, H., ODUMERU, J.A. and GRIFFITHS, M.W. 1998. Identification of contamination sources of Bacillus cereus in pasteurised milk. Int. J. Food Microbiol. 43, 159-171.

MARTIN, B., GARRIG, A.M., HUGAS, M., BOVER-CID, S., VECIANA-NOGUES, M.T. and AYMERICH, T. 2006. Molecular, technological and safety characterization of gram positive catalase-positive cocci from slightly fermented sausages. Int. J. Food Microbiol. 107, 148-158.

MONFREDINI, L., SETTANNI, L., POZNANSKI, E., CAVAZZA, A. and FRANCIOSI, E. 2011. The spatial distribution of bacteria in Grana-cheese during ripening. Syst. Appl. Microbiol. 35, 54-63.

PÁCOVÁ, Z., VYHNÁLKOVÁ, A., LUKÁSOVÁ, J. and HOLEC, J. 1996. Identification of aerobic and facultatively anaerobic sporulating bacteria isolated during the primary milk collection. Vet. Med. (Praha) 41, 19-23.

PARK, Y.-D., LEE, H.B., YI, H., KIM, Y., BAE, K.S., CHOI, J.E., JUNG, H.S. and CHUN, J. 2005. Pseudomonas panacis sp. nov., isolated from the surface of rusty roots of Korean ginseng. Int. J. Syst. Evol. Microbiol. 55, 1721-1724.

PASCIAK, M., HOLST, O., LINDNER, B., MIERZCHAL, A., GRZEGORZEWICZ, M., MORDARSKA, H. and GAMIAN, A. 2004. Structural and serological characterization of the major glycolipid from Rothia mucilaginosa. Biochim. Biophys. Acta 1675, 54-61. 
PEARCE, L.E., SMYTHE, B.W., CRAWFORD, R.A., OAKLEY, E., HATHAWAY, S.C. and SHEPHERD, J.M. 2012. Pasteurization of milk: The heat inactivation kinetics of milk-borne dairy pathogens under commercial-type conditions of turbulent flow. J. Dairy Sci. 95, 20-35.

PINTADO, M.E., MACEDO, A.C. and MALCATA, F.X. 2001. Review: Technology, chemistry and microbiology of whey cheeses. Food Sci. Technol. Int. 7, 105-116.

PINZON-SANCHEZ, C. and RUEGG, P.L. 2011. Risk factors associated with short-term post treatment outcomes of clinical mastitis. J. Dairy Sci. 94, 3397-3410.

QUATTARA, H.G., REVERCHON, S., NIAMKE, S.L. and NASSER, W. 2011. Molecular identification and pectate lyase production by Bacillus strains involved in cocoa fermentation. Food Microbiol. 28, 1-8.

REGINENSI, S.M., GONZALEZ, M.J., OLIVERA, J.A., SOSA, M., JULIANO, P. and BERMUDEZ, J. 2011. RAPD-based screening for spore-forming bacterial populations in Uruguayan commercial powdered milk. Int. J. Food Microbiol. 148, $36-41$.

SAITOU, N. and NEI, M. 1987. The neighbour-joining methods: A new method for reconstructing phylogenetic trees. Mol. Biol. Evol. 4, 406-425.

SCHELDEMANN, P., GOOSSENS, K., RODRIGUEZ-DIAZ, M., PIL, A., GORIS, J., HERMAN, L., DE VOS, P., LOGAN, N.A. and HEYNDRICKX, M. 2004. Paenibacillus lactis sp. nov., isolated from raw and heat-treated milk. Int. J. Syst. Evol. Microbiol. 54, 885-891.

SUTHERLAND, A.D. and MURDOCH, R. 1994. Seasonal occurrence of psychrotrophic Bacillus species in raw milk and studies on the interactions with mesophilic Bacillus sp. Int. J. Food Microbiol. 21, 279-292.

VARNAM, A.H. and SUTHERLAND, J.P. 2001. Dairy protein products. In Milk and Milk Products, Technology, Chemistry and Microbiology, Vol. 1 (R. Bloom, ed.) Food Products Series, pp. 154-169, Aspen Publications, New York, NY. 